\title{
The European Green Deal - More Than Climate Neutrality
}

The European Green Deal aims at climate neutrality for Europe by 2050, implying a significant acceleration of emission reductions. To gain the necessary support, it needs to reduce regional and social inequalities in Europe. We present objectives in terms of jobs, growth and price stability to complement the emission reduction targets and sketch a proof-of-concept investment profile for reaching these goals. Substantial additional annual public investments, of about $1.8 \%$ of pre-COVID-19 GDP, are proposed for the next decade. Their allocation includes retrofitting the European building stock, consciously fostering a renewal of the European innovation system as well as complementary measures in the fields of education and health. The scenario outlined in this article is meant as an input to the urgently needed discussion on how the European Green Deal can shift the EU economy to a new development path that realises a carbon-neutral Europe by 2050 while strengthening European cohesion.

The European Green Deal (EGD) has been proposed as a mission for Europe to become the world's first carbonneutral continent by 2050 , and to strengthen European cohesion through this mission (von der Leyen, 2019). Both goals present massive challenges; we argue that they can be turned into not only an environmental, but also a social and economic opportunity.

(c) The Author(s) 2021. Open Access: This article is distributed under the terms of the Creative Commons Attribution 4.0 International License (https://creativecommons.org/licenses/by/4.0/).

Open Access funding provided by ZBW - Leibniz Information Centre for Economics.

Sarah Wolf, Freie Universität Berlin; and Global Climate Forum, Berlin, Germany.

Jonas Teitge, Zuse Institut Berlin; and Global Climate Forum, Berlin, Germany.

Jahel Mielke, Global Climate Forum, Berlin, Germany.

Franziska Schütze, German Institute for Economic Research (DIW Berlin); and Global Climate Forum, Berlin, Germany.

Carlo Jaeger, Arizona State University, Phoenix AZ, USA; and Beijing Normal University, China.
The target to cut greenhouse gas (GHG) emissions by at least $55 \%$ by 2030 (compared to 1990), proposed by the European Commission, has gained geopolitical weight with Chinese plans to peak carbon emissions in 2030 and reach carbon neutrality no later than 2060 (UN, 2020). A whole range of nations and regions has declared similar goals.

Over the last two decades, processes of divergence and polarisation have been unfolding in the EU and the eurozone (Gräbner et al., 2020; Algan et al., 2017). With the coronavirus pandemic and the measures taken to control its spreading, these processes have intensified. Expected growth rates for Spain, Italy and Portugal in 2020 are $-11 \%,-8.8 \%$ and $-7.6 \%$ respectively; the expected losses for Germany and Denmark are less severe, at $-5 \%$ and $-3.5 \%$ respectively (European Commission, 2020e). At the same time, the fiscal impulse in response to the crisis amounts to $8.3 \%$ of GDP in Germany and 5.5\% in Denmark, whereas in Spain, Italy and Portugal it amounts to 4.3\%, 3.4\% and 2.4\% respectively (Anderson et al., 2020). The EU recovery plan promises to mitigate these processes - as should the EGD.

A European climate strategy aiming at carbon neutrality by 2050 can only be successful if it shifts the economy to a new development path that generates broad social and political support early on. This means it needs to come with tangible improvements of living conditions for European citizens at large, across all regions and social groups. Grounded in a line of research about how climate 
policy can trigger a transition to a new growth path (Jaeger et al., 2011, 2015; Jaeger, 2012; Schütze et al., 2017), this article presents a feasibility check of such a shift.

A historical transition like the EGD cannot and should not be planned in detail all the way to 2050 , nor is it sufficient to declare an ambitious 2050 goal. First steps need to be specified. In this sense, we sketch a proof-of-concept EGD investment profile for 2021-2030 and explore its potential consequences in terms of emissions, unemployment, growth and inflation. Analysing what it takes to achieve the strictest GHG emission reduction target of $60 \%$ (as proposed by the European Parliament) technically, economically and socially, the main findings would remain in place also for the $55 \%$ target.

The quantitative scenario outlined is meant as a contribution to further discussions on designing and implementing the EGD in its first decade. By 2030, key developments will need to be carefully documented and evaluated in order to apply what is learned in the following decades.

\section{Relevant emissions dynamics and the path towards a carbon-neutral Europe}

Among the multitude of dynamics relevant for the EGD, the EU's GHG emissions can be rather reliably specified; as illustrated in Figure 1, the pattern shows variation around a linear trend. In the baseline year of current climate policy, 1990, GHG emissions of today's EU27 countries stood at $4,857 \mathrm{Mt} \mathrm{CO}_{2}$ equivalent $\left(\mathrm{CO}_{2} \mathrm{e}\right){ }^{1}$ This includes $\mathrm{CO}_{2}$ emissions and other gases like methane, calculated by $\mathrm{CO}_{2}$ e. By 2018 , they had fallen to $3,764 \mathrm{Mt}$ (with 3,055 $\mathrm{Mt} \mathrm{CO}_{2}$ emissions), i.e. the decline was about $39 \mathrm{Mt}$ per year on average (Eurostat, 2020b). ${ }^{2}$ A $60 \%$ reduction by 2030 implies a target of $1,943 \mathrm{Mt}$. This requires an annual decline in the order of $162 \mathrm{Mt}$, a massive break with the trend of past decades. ${ }^{3}$ After 2030, two decades remain for reducing the remaining 1,943 Mt to zero, implying an average annual decline of $97 \mathrm{Mt}$. It is reasonable to expect that if the challenging 2030 target is reached, the EU will then be able to move towards climate neutrality in 2050.

With the pattern thus illustrated, emission dynamics fluctuate around three different speeds of linear decline: a phase of sluggish reduction for the past three decades,

1 We use emissions data excluding international aviation

2 At the time of writing, the most recent data available are those for 2018. The 2019 value is estimated by subtracting the average annual decline of $39 \mathrm{Mt}$ from the 2018 figure, and the required reductions for 2020-2030 are computed from this.

3 The $55 \%$ target implies an annual decline of $140 \mathrm{Mt}$ - hardly reducing the break with the past.
Figure 1

Climate-neutral EU27 by 2050 via a $60 \%$ greenhouse gas emission reduction by 2030

in $\mathrm{Mt}_{\mathrm{CO}_{2} \mathrm{e}}$

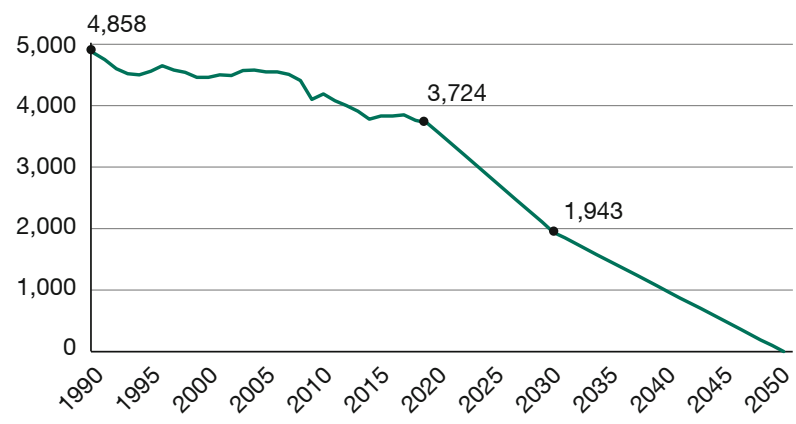

Sources: GHG Emissions 1990-2018 from Eurostat (2020b); 2019 own estimation following trend 1990-2018.

a breakthrough decade starting at the time of writing, and two decades for bringing the effort to completion. Once available, the EU27 figures for 2020 may seem on track with emission reductions required for the coming decade, but the economic recovery expected for 2021 is likely to increase emissions again, ${ }^{4}$ leaving little time for achieving the 2030 goal.

This is relevant for the role of carbon prices as they can quickly influence the way existing capital stocks and other durable goods are used. But they fail to incentivise the quick replacement of exisiting stocks necessary for carbon neutrality (Patt and Lilliestam, 2018). Therefore, direct regulation is as important as carbon prices, as shown by the rapid impact of recent EU emission rules for cars (Financial Times, 2020).

Neither carbon prices nor direct regulations, however, will automatically trigger the investments needed for building the infrastructure to support a carbon-neutral Europe. Public investment is therefore indispensable. At the same time, public investment is needed to overcome the widely underestimated slack in the EU economy (Brooks and Fortun, 2020). Because of this slack, well-targeted public investment can reduce GHG emissions without increasing costs for industries, but rather by creating additional output, employment and welfare - i.e. a new development path (Jaeger et al., 2011). The basic idea underlying this article hence is that the key to earning the buy-in of European citizens for the EGD lies in unleashing the full potential of the European economy by combining carbon

4 In the winter 2021 forecast, the EU Commission expected a GDP decline of $6.3 \%$ for the year 2020 as a whole and a rebound of $3.7 \%$ for 2021 (European Commission, 2020e). 
taxes and direct regulation with EGD-oriented public investment.

\section{Further criteria for a new development path}

Change required for carbon neutrality can be perceived as change for the better if the European Green Deal generates tangible and widely shared economic and social benefits. Along with the breakthrough in emission reductions discussed above, we consider the following additional criteria important:

Unemployment rates below $7 \%$ and rates of youth unemployment below 15\% across EU member states by 2030. Overall unemployment in the EU $6.3 \%$ in the last quarter of 2019) 5 is not a sufficient criterion since unemployment figures for individual countries differ widely. Pre-COVID-19 levels ranged from 2\% in the Czech Republic, 3.1\% in Germany and $3.3 \%$ in Poland to $10 \%$ in Italy, $14.1 \%$ in Spain and 17.3\% in Greece (Eurostat, 2020f).

Similarly, youth unemployment rates were $29.2 \%$ in Italy, $32.5 \%$ in Spain and 35.2\% in Greece before the current crisis (Eurostat, 2020g) and are expected to rise significantly (Bacher and Tamesberger, 2020). The EGD can be experienced as an attractive perspective if it improves the current situation quickly, reaching and stabilising the stated goals by 2030 .

Strengthening convergence and cohesion. A related issue is reducing inequality of wealth and income, both between and within European countries. The latter, in particular, has been increasing recently (Blanchet et al., 2019). Agreeing with European Parliament President David Sassoli that the "Green Deal must be an opportunity to fight inequality" (European Parliament, 2020), we leave the specification of measurable goals on this issue to further, urgent and promising research. ${ }^{6}$

Average annual growth rates of EU GDP clearly above $2 \%$ until 2030. The EGD should support a fast and strong recovery from the current crisis and help avoid another period of sluggish growth at a lower level than before the pandemic, as happened after the financial crisis. Between crises, growth rates hovered around 2\% (European Commission, 2012; Trading Economics, 2019) and preCOVID-19 growth estimates relevant for the decade 20202030 pointed to a range between 1.5\% and 2\% (Gros and Alcidi, 2013; European Commission, 2012; PwC, 2017;

5 Current estimates see the COVID-19 pandemic leading to a rise in EU unemployment to around $7.7 \%$ in 2020 and around $8.6 \%$ in 2021 (European Commission, 2020a).

6 European Commission (2015) may be a good starting point.
Knoema, 2019; Trading Economics, 2019). For the coming decade, a tangible improvement of the new development path over the previous one is needed. To the extent that improvements in other indicators of well-being - e.g. of public health, harmony with nature, fairness, fulfilling jobs - should materialise, such indicators may later become more salient than GDP growth (Stiglitz et al., 2018; Jakob et al., 2020).

Inflation rates in line with price stability as defined by the $E C B$, i.e. currently "below, but close to, $2 \%$ over the medium term" (European Central Bank, 2019). ${ }^{7}$ Runaway inflation experiences are well documented at levels higher than $10 \%$, but there is no evidence suggesting that a monetary policy focusing on a stabilisation goal of, say, $4 \%$ would be problematic, quite the opposite (Ball, 2014). However, an EGD driving inflation higher than the defined upper bound would be obstructed by the ECB raising interest rates. Most observers consider inflation rates since the financial crisis in the EU27 - averaging 1.55\% between 2008 and 2019 (Eurostat, 2020c) - too low. Forecasts for the COVID-19 crisis are lower still: $0.7 \%$ for 2020 and $1.5 \%$ for 2021 (European Commission, 2020e). Inflation rates substantially below $2 \%$ are an indicator of slack and signal economic depression. The EGD should help to overcome this condition in the short run and avoid it in the long run.

\section{A proof-of-concept investment profile up to 2030}

In view of the above criteria, for the first decade of the EGD, we consider the following annual expenditure profile, summarised in Table 1, building on two previous proposals (Wolf et al., 2020; Creel et al., 2020). The first items are geared directly towards emission reductions.

\section{A European electricity grid for $100 \%$ renewables}

The electricity industry accounts for around 1,015 $\mathrm{Mt} \mathrm{CO}_{2} \mathrm{e}$, or $27 \%$ of EU emissions (European Environment Agency, 2020b). Creel et al. (2020) describe the necessity and feasibility of frontloading investments into the European electricity grid for $100 \%$ renewables by 2050 (no fossil or nuclear fuels) described by the European Network of Transmission System Operators for Electricity (ENTSO-E, 2015). Their proposal amounts to an average of about $€ 25$ billion annually until 2030.

\section{Transforming the car-based mobility system}

There were around 233 million passenger cars in the EU27 in 2018 (computed from the European Automobile Manu-

7 For a discussion on inflation targets, as part of the ongoing strategy revision of the ECB, see Bremus et al. (2020). 
Table 1

Annual EGD investment streams for 2021-2030, emission reductions and main further effects

\begin{tabular}{|c|c|c|c|c|}
\hline $\begin{array}{l}\text { Share } \\
\text { (rounded) }\end{array}$ & $\begin{array}{l}\text { billion } \\
\text { euro }\end{array}$ & Field & $\mathrm{Mt} \mathrm{CO} \mathrm{e}_{2}$ & Societal benefits \\
\hline & & $\begin{array}{l}\text { Emission reduction } \\
\text { trend preceding the } \\
\text { EGD }\end{array}$ & 39 & \\
\hline $10 \%$ & 25 & $\begin{array}{l}\text { Frontloading a } 100 \% \\
\text { renewables grid }\end{array}$ & 30 & \\
\hline $8 \%$ & 20 & $\begin{array}{l}\text { Transforming the } \\
\text { car-based mobility } \\
\text { system }\end{array}$ & 18 & Health \\
\hline $8 \%$ & 20 & European Silk Road & 20 & Growth, cohesion \\
\hline $27 \%$ & 70 & $\begin{array}{l}\text { Energy renovation of } \\
\text { buildings }\end{array}$ & 24 & Employment \\
\hline $12 \%$ & 30 & $\begin{array}{l}\text { R\&D for energy- } \\
\text { saving digitalisation }\end{array}$ & 30 & \\
\hline $12 \%$ & 30 & $\begin{array}{l}\text { Advanced green vo- } \\
\text { cational education }\end{array}$ & catalyst & $\begin{array}{l}\text { Convergence, } \\
\text { employment }\end{array}$ \\
\hline $12 \%$ & 30 & $\begin{array}{l}\text { European break- } \\
\text { through innovation } \\
\text { system }\end{array}$ & catalyst & Employment \\
\hline $4 \%$ & 10 & $\begin{array}{l}\text { Subcontracting } \\
\text { management tasks } \\
\text { for EGD }\end{array}$ & catalyst & Employment \\
\hline $8 \%$ & 20 & $\begin{array}{l}\text { European planetary } \\
\text { health policy }\end{array}$ & catalyst & $\begin{array}{l}\text { Health, } \\
\text { employment }\end{array}$ \\
\hline \multirow[t]{2}{*}{$100 \%$} & 255 & $\begin{array}{l}\text { Total public invest- } \\
\text { ment per year }\end{array}$ & & \\
\hline & & $\begin{array}{l}\text { Total emission } \\
\text { reductions per year }\end{array}$ & 161 & \\
\hline
\end{tabular}

Source: Authors' calculation.

facturers Association, 2019), responsible for about $15 \%$ of the EU27 $\mathrm{CO}_{2}$ emissions (European Environment Agency, 2020b), i.e. $469 \mathrm{Mt} \mathrm{CO}_{2}$, or about 2 t per car. ${ }^{8}$ Currently, passenger transport uses almost $83 \%$ passenger cars, 9\% motor coaches and under 8\% rail (Eurostat, 2020e). Emissions can be reduced via more efficient cars and via shifting the modal split, e.g. increasing the share of public transportation, which is four times more efficient in terms of $\mathrm{CO}_{2}$ than cars (UITP, 2014). The latter option can provide additional benefits in terms of noise, air quality, road safety and health. For cities, large variations in modal split - e.g. in London the share of cars is $10 \%$, in Bilbao that of walking is $65 \%$ (EPOMM, 2020) - suggest possibilities for a sustainable mobility system.

8 European Commission (2020d) states 12\%, but an average of about $160 \mathrm{~g} \mathrm{CO}_{2} / \mathrm{km}$ tailpipe emissions (ICCT, 2018) and an average of $12,000 \mathrm{~km} /$ year for the EU as a whole (Odyssee-Mure, 2020) is consistent with the former source.
For a breakthrough towards sustainable mobility (not only for cities), we consider an annual public investment of $€ 20$ billion reasonable, rounding up the infrastructure investments proposed by Wolf et al. (2020) for electric charging stations ( $€ 5$ billion), cycling ( $€ 5$ billion) and local public transport (€10 billion).

\section{A European Silk Road}

Heavy duty trucks and buses were responsible for about $5.5 \%$, or $208 \mathrm{Mt}$, of EU GHG emissions in 2018 (European Environment Agency, 2020b). As Creel et al. (2020) argue, it is time to balance the Chinese Belt and Road initiative with a European Silk Road initiative (see also Holzner et al., 2018; Mangalagiu et al., 2016). In terms of emissions, this offers a unique opportunity for a shift from yesterday's heavy vehicles to tomorrow's trains.

If the financing is organised through a special purpose vehicle (SPV) established by EU countries so as to be able to issue long-term bonds at near zero (positive or negative) real interest rates, public investment can be rather small compared to the overall volume. To set up the SPV and to ensure positive spillovers to the European transport network, an annual flow of $€ 20$ billion will suffice. The experience with the European Fund for Strategic Investments (EFSI), supporting investments of around $€ 500$ billion, using $€ 33.5$ billion of public investment and guarantees in five years, can serve as an example (European Investment Bank 2020). ${ }^{9}$

\section{Accelerating the energy renovation of the building stock}

Buildings are accountable for $36 \%$ of the $\mathrm{CO}_{2}$ emissions in the EU (European Commission, 2016a), presently about 1,100 Mt. The largest part of these emissions, about 750 Mt, is due to residential buildings. ${ }^{10}$ With about 16 billion $\mathrm{m}^{2}$ of residential floor space,,$^{11}$ the average is about $47 \mathrm{~kg} /$ $\mathrm{m}^{2} .{ }^{12}$ Until now, only about $0.4 \%$ to $1.2 \%$ (European Commission, 2016b) of the building stock has been renovated each year, i.e. at most about 150 million $\mathrm{m}^{2}$. At this pace, renovating the inefficient European building stock - esti-

9 For an analysis of EFSI-funded projects, see Schütze et al. (2020); unlike for EFSI, here the allocation of funds needs to be shifted away from funding airports and highways, e.g. to railways.

10 The calculation is based on relative energy intensity of residential and non-residential buildings as stated by Buildings Performance Institute Europe (2011)

11 Calculated by subtracting UK's 4 billion $\mathrm{m}^{2}$ from a total EU28 floor space of 25 billion $\mathrm{m}^{2}$ and taking into account that about $25 \%$ of the total floor space is non-residential (European Parliament, 2016a).

12 This is a very crude estimate obtained by dividing total emissions by total square metres. However, as Coma et al. (2019) find, data on the European building stock are scarce and spread over a factor of ten for their analysis of six European countries. 
mated at about $75 \%$ of the total (European Commission, 2016a) - would take more than 60 years.

To accelerate energy renovation of residential buildings, we consider an annual investment in the order of $€ 70$ billion. Present estimates of energy renovation costs range from $€ 200$ to $€ 450$ per square metre, depending on the depth of renovation (European Parliament, 2016b). Providing $€ 100$ in grants per square metre out of $€ 70$ billion, on the condition that house owners invest at least $€ 200$ per square metre, would allow for the energy renovation of about 700 million $\mathrm{m}^{2}$ per year. ${ }^{13}$

Research and development in digitalisation for energy saving

While the information and communication technology (ICT) industry produces GHG emissions through its own energy use, digitalisation can lead to much larger emission reductions through energy savings - in buildings, transport, industry, households, agriculture and more. With the exception of some specialised niches, the EU ICT sector lags behind its main global competitors. In the $\mathrm{EU}$, research and development (R\&D) investment by ICT businesses was about $0.2 \%$ of GDP, and the amount publicly funded was less than $0.05 \%$ of GDP in recent years (European Commission, 2019). We suggest an additional public investment stream of $€ 30$ billion, i.e. another $0.2 \%$ of GDP, to change this situation in the direction of the EGD. These should be disbursed in such a way that they increase incentives for ICT companies to invest in applications promising large-scale energy savings and carry out the respective $R \& D$ in cooperation with building companies as well as regulating authorities.

While the following investments cannot be as directly associated with emission reductions, they are nevertheless essential for such reductions to happen under the given circumstances, e.g. to bring down emissions from industry.

\section{Advanced green vocational education}

The EGD will disrupt occupational biographies in a number of sectors and requires innovative forms of advanced vocational training nurturing new skills on a broad scale (Jaeger, 2014). An annual investment stream of $€ 30$ billion can provide education opportunities, including a year of training for about $10 \%$ of the workforce in the construction sector (Wolf et al., 2020).

13 Grants should be disbursed on a first come, first served basis, with suitable regulations giving a strong signal to home owners that sooner or later their buildings will have to satisfy stringent energy standards.

\section{A European breakthrough innovation system}

Since World War II, Europe has excelled in continuously improving existing technologies and practices, but not in generating breakthrough innovations. Catching up on such innovations developed elsewhere has worked occasionally, as in the case of planes and high-speed trains. However, for carbon neutrality, breakthrough innovations will be crucial to bring down the costs of transforming existing urban structures and in fields like green hydrogen, agriculture and ICT. In the view of the EGD, industry needs a combination of challenges from regulation and an overhaul of the European innovation system (see, e.g. Mazzucato 2016, 2018).

The US innovation system, which clearly has breakthrough capacity, differs in institutional arrangements and in funding magnitude: ${ }^{14}$ US public R\&D expenditures at the federal level alone (i.e. without states like Massachusetts or California) are in the order of $0.8 \%$ of GDP (Hourihan and Parkes, 2019). $R \& D$ expenditures of the $E U$ are less than one-tenth of that - in 2019, e.g. the EU umbrella programme for R\&D, Horizon 2020, amounted to around $€ 12$ billion, i.e. $0.075 \%$ of (then EU28) GDP. We hence suggest an additional investment stream of at least $€ 30$ billion, or about $0.2 \%$ of (now EU27) GDP, as a step in the direction of an innovation system capable of breakthroughs centred on the EGD.

\section{Subcontracting management tasks}

Realising the EGD will require greatly amplifying the managerial capabilities of the EU and its member states. As in many other domains, public-private partnerships are important here. Carefully organised, an annual investment of $€ 10$ billion in human capital can become a unique experience of mutual learning by public administration and private enterprise for management at the local, national and European levels.

\section{A European planetary health policy}

Finally, it was the COVID-19 crisis that triggered fundamental change in financial resources becoming available to tackle common challenges in the EU. To consolidate this process, it is vital to embed the goal of climate neutrality in the broader ambition of tackling the risks and seizing the opportunities of the Anthropocene. As a response to the coronavirus pandemic, the EU should develop a European planetary health policy (Whitmee and Haines, 2015). Initial tasks include building the capability

14 A discussion of an equivalent of the US Defense Advanced Research Projects Agency, with the EGD acting as a its backbone rather than the military is beyond the scope of the present paper (but see Marin, 2020). 
and infrastructure for real-time monitoring of European health dynamics, initiating rapid large-scale contact tracking and testing, the cross-border transfer of medical equipment, vaccines and pharmaceuticals, step-wise development of health-conscious socio-ecological systems and expanding the global professional information exchange beyond intergovernmental channels.

Estimates for appropriate annual investments vary between $€ 20$ and $€ 70$ billion (European Commission, 2020c). As the long-term establishment of a European planetary health policy will be a stepwise process, we consider an initial budget of $€ 20$ billion per year, to be complemented by investments of member states.

The proposed investment profile amounts to an annual public investment of $€ 255$ billion, which is about $1.8 \%$ of the EU27's 2019 GDP and is in the range of volumes previously discussed in view of the EGD (European Commission, 2020b).

\section{Feasibility check}

To show that the investment profile outlined can shift the EU economy to a new development path compatible with the proposed criteria, we roughly estimate plausible effects of the investments, based on literature and basic calculations. The obvious first step concerns emission reductions.

The emission reduction trend before the EGD. As the investments proposed here are in addition to existing measures, the average annual reductions of the past three decades (about $40 \mathrm{Mt}$ of $\mathrm{CO}_{2}$ e per year) form the basis on which to build. GHG emissions per capita differ widely among European countries, as does, e.g. carbon intensity in electricity generation - from Sweden's $13 \mathrm{~g}$ $\mathrm{CO}_{2} / \mathrm{kWh}$ to $773 \mathrm{~g} \mathrm{CO}_{2} / \mathrm{kWh}$ in Poland (European Enviroment Agency, 2018). This leaves room for a continuation of the previous trend if countries can catch up to the least carbon-intensive ones.

Frontloading of a $100 \%$ renewables European electric grid. Presently, renewables in the EU make up $15 \%$ of total energy use, and the state of the grid is a key hindrance to rapidly expanding that share. Frontloading the $100 \%$ scenario proposed by the European Network of Transmission Operators for Electricity can deliver $30 \mathrm{Mt}$ of annual emission reductions. As this corresponds to less than $3 \%$ of current emissions from electricity production, it is a conservative estimate.

Transforming the car-based mobility system. With tailpipe emissions of an average car of about $160 \mathrm{~g} \mathrm{CO}_{2} / \mathrm{km}$ (IC-
CT, 2018) and around $122 \mathrm{~g} \mathrm{CO}_{2} / \mathrm{km}$ for a new car in 2019 (European Environment Agency, 2020a), replacing an old car provides an efficiency gain of about $24 \%$. Investments in charging infrastructure will be critical to achieving the 2020/2021 average fleet emission target of $95 \mathrm{~g}$ $\mathrm{CO}_{2} / \mathrm{km}$ (European Commission, 2020d), corresponding to about $40 \%$ gained. About 9 million old cars were replaced in $2018 ;{ }^{15}$ similar numbers lead to emission reductions of about $7 \mathrm{Mt}$ if the greater efficiency gain is implemented. Further, we estimate that the investments outlined lead to a modal shift of $20 \%$ switching from passenger cars to an improved public transport system and $5 \%$ switching to biking and walking by 2030 . Roughly, that corresponds to an annual modal shift of $2 \%$ and $0.5 \%$ respectively. Since each percent of the modal split using cars corresponds to $5.65 \mathrm{Mt}$ of emissions, ${ }^{16}$ this would save another $11.3 \mathrm{Mt}$, resulting in reductions of 18 Mt annually.

The European Silk Road. Today's railways are up to nine times less $\mathrm{CO}_{2}$ intensive than the road (Finger et al., 2019), and a European Silk Road would constitute a "big push" for a European train-centred freight system of the future (Creel et al., 2020). According to CER (2015), a doubling of rail freight transport, with the freight shifted from roads, could result in a reduction of GHG emissions of around 45-55 Mt $\mathrm{CO}_{2}$ e per year. As such an initiative takes time to realise its full potential, we estimate emission reductions in the order of $20 \mathrm{Mt} \mathrm{CO}_{2}$ e per year.

Accelerating the energy renovation of the building stock. Turning an average inefficient building into an efficient building means reducing its emissions by around $75 \%,{ }^{17}$ or by an average of about $35 \mathrm{~kg} \mathrm{CO}$ per square metre. Renovation of about 0.7 billion $\mathrm{m}^{2}$ per year, as sketched above, then decreases emissions by about $24.5 \mathrm{Mt}$.

$R \& D$ in digitalisation for energy saving. Estimates for $\mathrm{CO}_{2}$ emission reduction potential through ICT range from 0.1\%-1.0\% per year for households alone (Bastida et al., 2019 ) or to up to $3.7 \%$ across the whole society (British Telecommunications, 2019). The Global Enabling Sustainability Initiative (GeSI, 2015) estimates net GHG emission reductions in the order of $1.3 \%$ per year, corresponding to just under $50 \mathrm{Mt} \mathrm{CO}_{2} \mathrm{e}$ in the EU27's early 2020s. To exclude energy savings already accounted for above, we conservatively estimate $30 \mathrm{Mt} \mathrm{CO}_{2}$ e per year.

15 In the EU27, 14.1 million cars were new (Eurostat, 2020d) in 2018, but the total number of cars increased by five million compared to 2017.

16 This is computed from the fact that $469 \mathrm{Mt}$ correspond to $83 \%$ of the modal split.

17 Energy Class A compared to E, or D compared to A+ (Enev Oline, 2014). 
Thus, the total annual emission reductions achievable with the proposed investment profile fit the requirements for the breakthrough decade 2020-2030, keeping in mind that investment streams into education, a breakthrough innovation system and a planetary health policy generally support these emission reductions.

Concerning the criterion of growth, €255 billion, slightly more than $1 \%$ of GDP, will lead to additional growth of at least $1.5 \%$ of GDP, due to a fiscal multiplier of at least 1.5 (Boitani and Perdichizzi, 2018). Together with the precrisis trend of around $1.5 \%$, the annual growth rate will total at least 3\%. According to the International Monetary Fund (2020), in conditions of high uncertainty, like those created by the COVID-19 crisis, the fiscal multiplier might even be larger than two, as the €255 billion would trigger further private investments. This does not consider important indirect effects, such as the role of technical change, nor the fact that training accelerates the rate of productivity growth (Sala and Silva, 2011), so that growth effects can be expected to be larger in the longer run.

The criterion of unemployment was defined at country level in view of the danger of divergence and the possibility of convergence in the EU. We consider the case of Greece, the EU country worst hit by unemployment, especially for youth. It has $2 \%$ of the EU population, about 800,000 unemployed in 2019 (Eurostat, 2020a) and a GDP of about $€ 200$ billion. Therefore, directing $5 \%$ of the $€ 255$ billion, i.e. about $€ 13$ billion, towards public investments in Greece would be a shock of about $6 \%$ of Greek GDP.

Under present conditions, employment would increase by about $1.2 \%$ over two years in response to a positive shock of $1 \%$ of GDP due to public investment (International Monetary Fund, 2020). Considering the resident working age population of about 3.8 million (Eurostat, 2020a), with the employment multiplier of 1.2 , this shock translates to about 270,000 additional jobs over two years, constituting concrete steps towards the proposed targets, especially if hiring young people is incentivised.

Significant amounts of EGD public investments will need to be directed towards countries with excessive unemployment rates, but of course in such a way that countries near to or at full employment still experience a substantial stimulus. If the EU as a whole can accelerate growth to $3 \%$, employment in Greece can further increase to meet the goals. By similar considerations, this also holds for other countries with unemployment rates currently above the stated goals.

At present, the main challenge for the ECB is to bring average inflation close to $2 \%$. The investment push consid- ered here would make this goal easier to reach, especially if wages catch up with productivity where they are lagging. The required increase of inflation would then facilitate an innovative dynamic of the overall economy, keep the danger of deflation at bay and create leeway for policy responses in future crises.

Conversely, to avoid a rise of inflation above the target set by the ECB, the quality of the European innovation system and the development of new forms of vocational education become crucial. Improvements in these areas create the capacity and flexibility needed to overcome bottlenecks that might lead to problematically high rates of inflation.

\section{A broader perspective}

The present analysis is meant as an initial step in a broader research programme for understanding how Europe, and ultimately also other parts of the world, can shift to a new development path characterised by reducing emissions and increasing well-being.

Once such a new development path is reached, the level of public investment required to maintain it is likely to be lower than the level needed to trigger the transition. Given a decade of large-scale directed technical change, shifting back to a "brown" trajectory once a "green" one has been implemented is unlikely (Acemoğlu et al., 2012); the change in behaviour and social norms that leads to improved living conditions, such as cities with less pollution and noise (Gehl and Rogers, 2013) is also likely to remain.

It is setting in motion the virtuous circle of investment, well-being and innovation towards such a new development path that requires further research on potential options and development of the relevant technologies. Dialogue processes with decision-makers and citizens for deliberating what is desirable in a given context and negotiating contributions to the necessary changes are just as important (Mielke et al., 2017). Against this background, a co-evolutionary development of policies, technologies, cultural values and economic institutions seems to offer the best chance of successfully designing and implementing the European Green Deal.

The structure of a Green Deal outlined here is intended as a proof of concept. It aims to encourage discussion of elements of the EGD and related orders of magnitude that can lead to a shift to the new development path indicated. It also points to questions that will need answering, such as how to create a European innovation system capable of the breakthrough innovations needed to decarbonise not only Europe but the world economy as a whole. 
A related and even more daunting challenge lies in establishing a common will to realise the European Green Deal across EU member states. The nationally fragmented initial response to COVID-19 has confirmed the need for reversing the trend of decreasing European cohesion, observable in rising support for anti-European parties in many countries, with Brexit as its most obvious example. It remains to be seen whether and how the ambitious mission of becoming the first climate-neutral continent may be turned into an opportunity for uniting the European people.

\section{References}

Acemoğlu, D., P. Aghion, L. Bursztyn and D. Hemous (2012), The Environment and Directed Technical Change, American Economic Review, 102(1), 131-166.

Algan, Y., S. Guriev, E. Papaioannou and E. Passari (2017), The European Trust Crisis and the Rise of Populism, Brookings Papers on Economic Activity, Fall edition, 309-382.

Anderson, J., E. Bergamini, S. Brekelmans, A. Cameron, Z. Darvas, M. Domínguez Jíménez, K. Lenaerts and C. Midoes (2020), The fiscal response to the economic fallout from the coronavirus, Bruegel datasets.

Bacher, J. and D. Tamesberger (2020), COVID-19 Crisis: How to Avoid a Lost Generation, Intereconomics, 55(4), 232-238, https://www.intereconomics.eu/contents/year/2020/number/4/article/covid-19-crisishow-to-avoid-a-lost-generation.html (17 February 2021).

Ball, L. (2014), The Case for a Long-Run Inflation Target of Four Percent, IMF Working Paper, WP/14/92, https://www.imf.org/external/pubs/ft/ wp/2014/wp1492.pdf (12 December 2019).

Bastida, L., J. J. Cohen, A. Kollmann, A. Moya and J. Reichl (2019), Exploring the role of ICT on household behavioural energy efficiency to mitigate global warming, Renewable and Sustainable Energy Reviews, 103, 455-462.

Blanchet, T., L. Chancel and A. Gethin (2019), How Unequal Is Europe? Evidence from Distributional National Accounts, 1980-2017, https://wid. world/document/bcg2019-full-paper/ (12 December 2019).

Boitani, A. and S. Perdichizzi (2018), Public Expenditure Multipliers in recessions. Evidence from the Eurozone, Università Cattolica del Sacro Cuore - Dipartimento di Economia e Finanza, https://dipartimenti.unicatt.it/economia-finanza-def068.pdf (23 February 2020).

Bremus, F., G. Dany-Knedlik and T. Schlaak (2020), Price Stability and Climate Risks: Sensible Measures for the European Central Bank, DIW Weekly Report, 10(14), 205-213, https://www.diw.de/de/ diw_01.c.745707.de/publikationen/weekly_reports/2020_14_1/price_ stability_and_climate_risks_sensible_measures_for_the_european central_bank.html (17 February 2021).

British Telecommunications (2019), The role of ICT in reducing carbon emissions in the EU, https://www.btplc.com/Purposefulbusiness/ Ourapproach/Ourpolicies/ICT_Carbon_Reduction_EU.pdf (28 January 2020).

Brooks, R. and J. Fortun (2020), Eurozone Output Gaps and the COVID-19 Shock, Intereconomics, 55(5), 291-296, https://www.intereconomics. eu/contents/year/2020/ number/5/article/eurozone-output-gaps-andthe-covid-19-shock.html (17 February 2021).

Buildings Performance Institute Europe (2011), Europe's buildings under the microscope, http://bpie.eu/wp-content/uploads/2015/10/HR EU_B_under_microscope_study.pdf (18 October 2020).

CER - The Community of European Railway and Infrastructure Companies (2015), Railroad and Enviroment Facts and Figures, https://www. cer.be/sites/default/files/publication/Facts\%20and\%20figures\%20 2014.pdf (10 October 2020).

Coma, J., J. M. Maldonado, A. de Gracia, T. Gimbernat, T. Botargues and L. F. Cabeza (2019), Comparative Analysis of Energy Demand and $\mathrm{CO}_{2}$ Emissions on Different Typologies of Residential Buildings in Europe, Energies, 12(12).

Creel, J., M. Holzner, F. Saraceno, A. Watt and J. Wittwer (2020), How to Spend it: A Proposal for a European Covid-19 Recovery Programme,
The Vienna Institute for International Economic Studies Policy Notes and Reports, 30, https://wiiw.ac.at/how-to-spend-it-a-proposal-fora-european-covid-19-recovery-programme-dlp-5352.pdf (17 February 2021).

Enev Online (2014), Einteilung in Energieeffizienzklassen, https://enevonline.com/enev_2014_volltext/anlage_10_einteilung_in_energieeffizienzklassen.htm (1 September 2020).

ENTSO-E (2015), Europe's future secure and sustainable electricity infrastructure eHighway2050 project results, https://docs.entsoe.eu/ baltic-conf/bites/www.e-highway2050.eu/fileadmin/documents/e highway2050_booklet.pdf (11 October 2020).

EPOMM (2020), TEMS - The EPOMM Modal Split Tool, http://epomm.eu/ tems/index.phtml (17 February 2020).

European Automobile Manufacturers Association (2019), ACEA Report Vehicles in use Europe 2019, https://www.acea.be/uploads/publications/ACEA_Report_Vehicles_in_use-Europe_2019.pdf (30 November 2020).

European Central Bank (2019), Inflation in the Euro Area, https://www. ecb.europa.eu/mopo/html/index.en.html (6 January 2020).

European Commission (2012), Global Europe 2050, European Union, https://ec.europa.eu/research/social-sciences/pdf/policy_reviews/ global-europe-2050-report_en.pdf (6 January 2020).

European Commission (2015), An ever closer Union amongst the people of Europe? - Rising inequalities in the EU and their social, economic and political impacts, Outcomes of EU-funded research, https://ec.europa. eu/research/social-sciences/pdf/policy_reviews/kina26814enc.pdf (15 November 2020).

European Commission (2016a), Energy performance of buildings directive: Factsheet, https://ec.europa.eu/energy/content/ factsheet-energy-performance-buildings-directive_en (17 January 2020).

European Commission (2016b), EU Building Stock Observatory, https:// ec.europa.eu/energy/topics/energy-efficiency/energy-efficient-buildings/eu-bso_en?redir=1 (8 February 2020).

European Commission (2019), The EU ICT Sector and its R and D Performance, https://ec.europa.eu/newsroom/dae/document.cfm?doc_ id $=59978$ (15 October 2020).

European Commission (2020a), Autumn 2020, European Economic Forecast, https://ec.europa.eu/info/sites/info/files/economyfinance/ecfin forecast_autumn_2020_overview_en.pdf (1 December 2020).

European Commission (2020b), Financing the green transition: The European Green Deal Investment Plan and Just Transition Mechanism, https://ec.europa.eu/commission/presscorner/detail/en/ip_20_17 (20 November 2020)

European Commission (2020c) Identifying Europe's recovery needs, https:// eur-lex.europa.eu/legal-content/EN/TXT/PDF/?uri=CELEX:52020SC00 98\&from=EN (25 November 2020).

European Commission (2020d), Reducing $\mathrm{CO}_{2}$ emissions from passenger cars, https://ec.europa.eu/clima/policies/transport/vehicles/cars_en (17 February 2021).

European Commission (2020e), Winter 2021 (Interim), European Economic Forecast, https://ec.europa.eu/info/sites/info/files/economyfinance/ip144_en_1.pdf (9 March 2021).

European Environment Agency (2018), Overview of electricity production and use in Europe, https://www.eea.europa.eu/data-and-maps/indicators/overview-of-the-electricity-production-2/assessment-4 (18 February 2020).

European Environment Agency (2020a), Average $\mathrm{CO}_{2}$ emissions from newly registered motor vehicles in Europe, https://www.eea.europa. eu/data-and-maps/indicators/average-co2-emissions-from-motorvehicles/assessment-2 (18 November 2020).

European Environment Agency (2020b), EEA greenhouse gas - data viewer, https://www.eea.europa.eu/ds_resolveuid/f4269fac-662f-4ba0-a416c25373823292 (19 November 2020).

European Investment Bank (2020), The European Fund for Strategic Investments: The Legacy, https://www.eib.org/en/publications/efsithe-legacy (17 February 2021)

European Parliament (2016a), Boosting Building Renovation: What potential and value for Europe?, https://www.europarl.europa.eu/RegData/etudes/ STUD/2016/587326/IPOL_STU(2016)587326_EN.pdf (8 October 2020).

European Parliament (2016b), Global Europe 2050, European Union, https:// www.europarl.europa.eu/RegData/etudes/STUD/2016/587326/IPOL STU(2016)587326_EN.pdf (17 January 2020). 
European Parliament (2020), Statement by European Parliament President David Sassoli to the World Economic Forum in Davos, https://www. europarl.europa.eu/the-president/en/newsroom/sassoli-enough-ofthe-obsession-with-profit-green-deal-must-be-an-opportunity-tofight-inequality (2 February 2020).

Eurostat (2020a), Employment and activity by sex and age - annual data, https://ec.europa.eu/eurostat/databrowser/view/Ifsi_emp_a/default/ table (2 December 2020).

Eurostat (2020b), Greenhouse gas emissions by source sector, https:// ec.europa.eu/eurostat/databrowser/view/ENV_AIR_GGE/default/table (15 Ocotber 2020).

Eurostat (2020c), HICP - inflation rate, https://ec.europa.eu/eurostat/databrowser/view/tec00118/default/table?lang=en (2 January 2020).

Eurostat (2020d), New registrations of passenger cars by type of motor energy and engine size, http://appsso.eurostat.ec.europa.eu/nui/ show.do?dataset=road_eqr carmot\&lang=en (12 March 2020).

Eurostat (2020e), Passenger transport statistics, https://ec.europa.eu/ eurostat/statistics-explained/index.php/Passenger_transport_statistics (17 July 2020).

Eurostat (2020f), Unemployment rate - annual data, https://ec.europa eu/eurostat/databrowser/view/tipsun20/default/table?lang=en (1 December 2020).

Eurostat (2020g), Unemployment rates, seasonally adjusted, https:// ec.europa.eu/eurostat/statistics-explained/index.php/Unemployment_statistics (20 January 2020).

Financial Times (2020, 15 October), Ford to pair with rivals to avoid EU fines over emissions, Financial Times, https://www.ft.com/content/ d8a17d40-e242-4fc6-aa8e-e5c4a121ba0e (15 October 2020).

Finger, M., S. Teodora and I. Lapenkova (2019), Green Finance and Sustainability: Which Role for Railways?, Robert Schuman Centre for Advanced Studies.

Gehl, J. and R. Rogers (2013), Cities for People, Island Press.

GeSi - Global e-sustainability initiative (2015), SMARTer2030 ICT Solutions for 21st Century Challenges, https:/unfccc.int/sites/default/ files/smarter2030 executive summary.pdf (13 October 2020).

Gräbner, C., P. Heimberger, J. Kapeller and B. Schütz (2020), Is the Eurozone disintegrating? Macroeconomic divergence, structural polarisation, trade and fragility, Cambridge Journal of Economics, 44, 647-669.

Gros, D. and C. Alcidi (2013), The Global Economy in 2030: Trends and Strategies for Europe, Centre for European Policy Studies, https://espas.secure.europarl,europa.eu/orbis/sites/default/files/generated/ document/en/The\%20Global\%20Economy\%20in\%202030.pdf (14 December 2019)

Holzner, M., P. Heimberger and A. Kochnev (2018), A European Silk Road, The Vienna Institute for International Economic Studies, https://wiiw. ac.at/a-european-silk-road-dlp-4608.pdf (19 October 2020).

Hourihan, M. and D. Parkes (2019), Federal R\&D budget trends: A short summary, https://www.aaas.org/news/federal-rd-budget-trends-shortsummary (25 November 2020)

ICCT (2018), Effects of battery manufacturing on electric vehicle lifecycle greenhouse gas emissions, https://theicct.org/publications/EV-battery-manufacturing-emissions (22 April 2020).

International Monetary Fund (2020), Fiscal Monitor: Policies for the Recovery, https://www.imf.org/en/Publications/FM/Issues/2020/09/30/ october-2020-fiscal-monitor (19 October 2020).

Jaeger, C. (2014), A Choice for China: What Role for Vocational Education in Green Growth?, China \& World Economy, 22(5), 55-75.

Jaeger, C. C. (2012), Scarcity and coordination in the global commons, in C. C. Jaeger, K. Hasselmann, G. Leipold, D. Mangalagiuy and J. D. Tábara (eds.), Reframing the Problem of Climate Change: From Zero Sum Game to Win-Win Solutions, Routledge, 85-101.

Jaeger, C. C., L. Paroussos, D. Mangalagiu, R. Kupers, A. Mandel and J. D. Tábara (2011), A New Growth Path for Europe - Generating Prosperity and Jobs in the Low-Carbon Economy, Synthesis Report, A study commissioned by the German Federal Ministry for the Environment, Nature Conservation and Nuclear Safety.

Jaeger, C. C., F. Schütze, S. Fürst, D. Mangalagiu, F. Meißner, J. Mielke G. Steudle and S. Wolf (2015), Investment-Oriented Climate Policy: An opportunity for Europe, A study commissioned by the German Federal Ministry for the Environment, Nature Conservation, Building and Nuclear Safety.
Jakob, M., W. Lamb, J. Steckel, C. Flachsland and O. Edenhofer (2020), Understanding different perspectives on economic growth and climate policy, WIREs Climate Change, 11(6).

Knoema (2019), European Union GDP Growth Forecast 2019-2024, Data and Charts, https://knoema.com/mewdmh/european-union-gdpgrowth-forecast-2019-2024-data-and-charts (1 December 2019).

von der Leyen, U. (2019), A Union that strives for more - My agenda for Europe, European Commission, https://ec.europa.eu/commission/ sites/beta-political/files/political-guidelines-next-commission_ en.pdf (1 December 2019).

Mangalagiu, D., F. Meissner, J. Mielke and C. Jaeger (2016), A Green Corridor for Europe Connecting the EU and the Balkans - Background Paper, No 1: the Western Balkans, Global Climate Forum, https:// globalclimateforum.org/fileadmin/ecf-documents/pdf/Microsoft Word_-_Green_Corridor_Study_GCF.docx.pdf (19 October 2020).

Marin, D. (2020), Europe Needs a DARPA, https://www.project-syndicate. org/commentary/germany-europe-need-government-technologyresearch-agency-by-dalia-marin-2020-02?barrier=accesspaylog (20 August 2020).

Mazzucato, M. (2016), From market fixing to market-creating: a new framework for innovation policy, Industry and Innovation, 23(2), 140156.

Mazzucato, M. (2018), Mission-oriented innovation policies: challenges and opportunities, Industrial and Corporate Change, 27(5), 803-815.

Mielke, J., H. Vermaßen and S. Ellenbeck (2017), Ideals, practices, and future prospects of stakeholder involvement in sustainability science, Proceedings of the National Academy of Sciences, 114(50).

Odyssee-Mure (2020), Change in distance travelled by car, https://www. odyssee-mure.eu/publications/efficiency-by-sector/transport/distance-travelled-by-car.html (22 November 2020).

Patt, A. and J. Lilliestam (2018), The case against carbon prices, Joule, 2(12), 2494-2498.

PwC (2017), The Long View - How will the global economic order change by 2050 ?, PricewaterhouseCoopers International, https://www.pwc. com/gx/en/world-2050/assets/pwc-the-world-in-2050-full-reportfeb-2017.pdf (12 December 2019).

Sala, H. and J. Silva (2011), Labor Productivity and Vocational Training: Evidence from Europe, Journal of Productivity Analysis, 40.

Schütze, F., S. Fürst, J. Mielke, G. A. Steudle, S. Wolf and C. C. Jaeger (2017), The role of sustainable investment in climate policy, Sustainability, 9(12), 2221.

Schütze F., J. Stede, M. Blauert and K. Erdmann (2020), EU taxonomy increasing transparency of sustainable investments, DIW Weekly Report, 51/2020.

Stiglitz, J., J.-P. Fitoussi and M. Durand (2018), Beyond GDP Measuring: What Counts for Economic and Social Performance, OECD Library

Trading Economics (2019), European Union GDP Annual Growth Rate, https://tradingeconomics.com/european-union/gdp-annual-growthrate (11 December 2019).

UITP (2014), Climate action and public transport, https://cms.uitp.org/ wp/wp-content/uploads/2020/10/Climate-action-and-PT.pdf (20 November 2020).

UN (2020, 4 March), Enhance solidarity to fight COVID-19, Chinese President urges, also pledges carbon neutrality by 2060 , UN News, https:// news.un.org/en/story/2020/09/1073052 (1 October 2020).

Whitmee, S., A. Haines, C. Beyrer, F. Boltz, A. G. Capon, B. F. de Souza Dias, A. Ezeh, H. Frumkin, P. Gong, P. Head, R. Horton, G. M. Mace, R. Marten, S. S. Myers, S. Nishtar, S. A. Osofsky, S. K. Pattanayak, M. J. Pongsiri, C. Romanelli, A. Soucat, J. Vega and D. Yach (2015), Safeguarding human health in the Anthropocene epoch: report of The Rockefeller Foundation - Lancet Commission on planetary health, The Lancet, 386,1973-2928.

Wolf, S., J. Mielke, F. Schütze, J. Teitge and C. C. Jaeger (2020), About the European Green Deal, GCF Working Paper, 1/2020, https://globalclimateforum.org/2020/03/11/new-gcf-working-paper-01-20-aboutthe-european-green-deal/. 